\title{
Impacts of temperature and precipitation on runoff in the Tarim River during the past $\mathbf{5 0}$ years
}

\author{
YuTing FAN ${ }^{1,2}$, YaNing $\mathrm{CHEN}^{1 *}$, WeiHong $\mathrm{LI}^{1}$, HuaiJun WANG ${ }^{1,2}$, XinGong $\mathrm{LI}^{3}$ \\ ${ }^{1}$ State Key Laboratory of Desert and Oasis Ecology, Xinjiang Institute of Ecology and Geography, Chinese Academy of Sci- \\ ences, Urumqi 830011, China; \\ ${ }^{2}$ Graduate University of Chinese Academy of Sciences, Beijing 100049, China; \\ ${ }^{3}$ Department of Geography, University of Kansas Lawrence, KS 66045, USA
}

\begin{abstract}
The relationship between climate change and water resources in the Tarim River was analyzed by combining the temperature, precipitation and streamflow data from 1957 to 2007 from the four headstreams of the Tarim River (Aksu, Hotan, Yarkant and Kaidu rivers) in the study area. The long-term trend of the hydrological time series including temperature, precipitation and streamflow were studied using correlation analysis and partial correlations analysis. Holt double exponential smoothing was used to fit the trends between streamflow and the two climatic factors of Aksu River, Hotan River and Yarkant River. The streamflow of the main stream was forecasted by Autoregressive Integrated Moving Average Model (ARIMA) modeling by the method of time series analysis. The results show that the temperature experienced a trend of monotonic rising. The precipitation and runoff of the four headstreams of the Tarim River increased, while the inflow to the headstreams increased and the inflow into the Tarim River decreased. Changes of temperature and precipitation had a significant impact on runoff into the four headstreams of the Tarim River: the precipitation had a positive impact on water flow in the Aksu River, Hotan River and Kaidu River, while the temperature had a positive impact on water flow in the Yarkant River. The results of Holt double exponential smoothing showed that the correlation between the independent variable and dependent variable was relatively close after the model was fitted to the headstreams, of which only the runoff and temperature values of Hotan River showed a significant negative correlation. The forecasts by the ARIMA model for 50 years of annual runoff at the Allar station followed the pattern of the measured data for the same years. The short-term forecasts beyond the observed series adequately captured the pattern in the data and showed a decreasing tendency in the Tarim River flow of 3.07\% every ten years. The results showed that global warming accelerated the water recharge process of the headstreams. The special hydrological characteristics of the arid area determined the significant association between streamflow and the two climatic factors studied. Strong glacier retreat is likely to bring a series of flood disasters within the study area.
\end{abstract}

Keywords: Tarim River Basin; climate change; hydrological change; water resources; streamflow

One of the most valuable resources in arid areas is water. It is the foundation of oasis ecosystem development and stability. Water is also an important environmental factor in arid areas. The streamflow trends and hydrological responses to climatic change within the Tarim River Basin have received much attention because of the basin's unique geographical location and the fragile ecological system (Yang et al., 2004). Developing water resources and protecting the environment of the Tarim River Basin have strategic significance not only for the survival and development of the watershed but also for the western development strategy (Sun et al., 2009). Hydrological and natural ecological conditions are changing significantly because of the utilization of water resources and high intensity of human economic and social activities over the past 50 years (Chen et al., 2004). Recently, the response of water resources and the natural environment to climate changes have been widely researched

\footnotetext{
Received 2010-10-23; accepted 2011-04-18

* Corresponding author: YaNing CHEN (E-mail: chenyn@ms.xjb.ac.cn)
} 
within the Tarim River Basin (Chen et al., 2009; Ye et al., 2009a, b; Zhang et al., 2010; Zhou et al., 2010). The Tarim River is a pure dissipative inland river with no production flow, and it entirely relies on water supply from its headstreams in the mountains. The surface runoff is $3.92 \times 10^{10} \mathrm{~m}^{3} / \mathrm{a}$, which comes mainly from snow-melt water resources on the western, southern and northern mountains (Hao et al., 2006). Analysis of the relationship between climate change and hydrological processes in the Tarim River Basin is necessary in order to predict future flow rates and water availability.

Previous studies have shown that annual average temperature and precipitation in the Tarim River Basin have increased significantly (Xu et al., 2007; Gao et al., 2008; Zhang et al., 2008; Duan et al., 2009). Meanwhile, the runoff has fluctuated with changes in temperature and precipitation (Tao et al., 2007; Zhang et al., 2008). Streamflow in the headwaters has increased significantly, which might be related to the increased snow-melt water caused by rising temperature (Shi, 2001; Shen et al., 2009). The average temperature in the Tarim River Basin has been rising, most noticeably since the late 1970s, and precipitation over this period has shown a fluctuating but significant upward trend ( $\mathrm{Li}$ et al., 2007). The discharge from headstreams had increased for many years because of increasing precipitation and temperature ( $\mathrm{Fu}$ et al., 2009). But the annual runoff in the mainstream of the river has tended to slightly decrease over the past 50 years (Wang et al., 2003). The annual runoff in the Tarim River may be affected by temperature changes, meanwhile, changes in precipitation impact the runoff of headstreams. However, the response of runoff to temperature and precipitation and the relationship between them is not clearly understood. This study set out to improve that understanding, through combining hydrological, temperature and precipitation data from the last 50 years, and analyzing the characteristics of the hydrological process and the response of runoff to temperature and precipitation changes in the Tarim River Basin.

\section{Study area}

The Tarim River Basin $\left(39^{\circ} 00^{\prime}-41^{\circ} 40^{\prime} \mathrm{N}, 80^{\circ} 30^{\prime}-88^{\circ} 30^{\prime} \mathrm{E}\right)$ is the generic term for the combination of the catchments of the Aksu River, Kashgar River, Yarkand River, Hotan River, Kaidu-Peacock River, Dina River, Weigan River, Kuqa River, and Keriya River, composed of 114 rivers in 9 stream systems (Duan et al., 2009). The total area of the Tarim River Basin is 1.02 $\times 10^{6} \mathrm{~km}^{2}\left(996,000 \mathrm{~km}^{2}\right.$ within Xinjiang), in which the land is divided into mountains (47\%), plains (22\%), deserts $(31 \%)$, and an arable land area of $1.36 \times 10^{6}$ $\mathrm{hm}^{2}$ (Xie et al., 2007). The Tarim River is mainly recharged by alpine glacier and snow melt water and precipitation, totaling $38.2 \times 10^{10} \mathrm{~m}^{3} / \mathrm{a}$ (Jiang et al., 2007). Due to the impacts of climate change and human activities, only Aksu River, Yarkand River, Hotan River and Kaidu River now supply water to the mainstreams Tarim River (Jiang et al., 2007). The Aksu River, Yarkand River and Hotan River join the Tarim River in the upper reaches, while the Kaidu River flows into the Tarim River in the lower reaches. The Tarim River Basin has a typical continental climate because it is far away from the ocean and surrounded by high mountains. It is extremely arid, with poor precipitation and strong potential evaporation (Zuo et al., 2006). The Tarim River is about $1,321 \mathrm{~km}$ long from the confluence composed of the Aksu, Hotan, and Yarkand rivers to Taitema Lake (Fig. 1).

\section{Methods}

The annual data of temperature, precipitation and runoff during the period of 1957-2006 were collected from six stations in the headstreams of the Tarim River and two stations on the Tarim River itself (Fig. 1). The Tongguzlok and Uruwat stations are located on the Hotan River, Kaqung station on the Yarkand River, Shrikilank and Xehera stations on the Aksu River and Dashankou station on the Kaidu River. Allar station is located on the mainstream and is the first hydrological station of the Tarim River while Kara station is located on the Tarim River at the junction between the middle and lower reaches. Therefore, this dataset may be regarded adequate to represent the large-scale temperature/precipitation/runoff variations occurring over the Tarim River Basin. The information of the selected stations in the basin is shown in Table 1. 


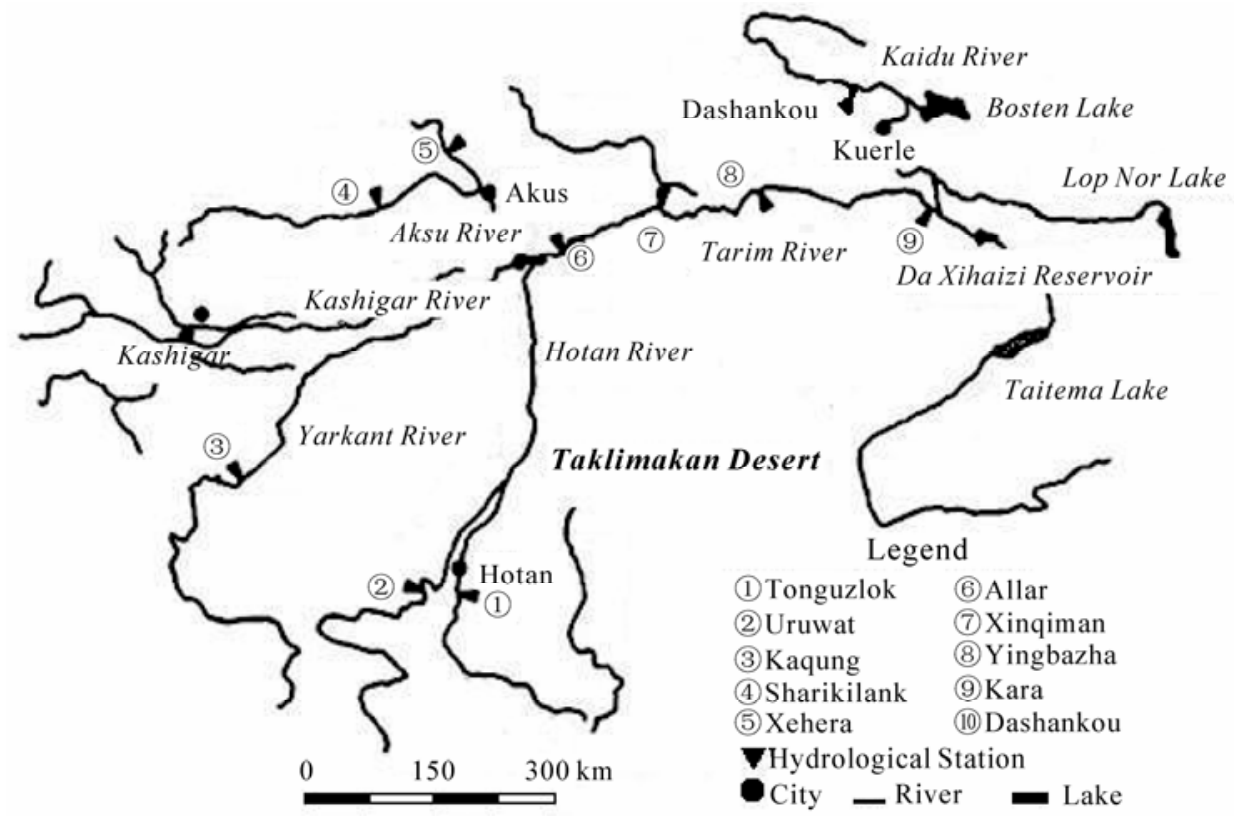

Fig. 1 The sketch map of the Tarim River Basin

Table 1 Main stations of the Tarim River

\begin{tabular}{|c|c|c|c|c|c|}
\hline Station & River system & Altitude (m) & Longitude & Latitude & Period \\
\hline Tongguzlok & Hotan River & 1,650 & $79^{\circ} 55^{\prime}$ & $36^{\circ} 49^{\prime}$ & 1957-2006 \\
\hline Uruwat & Hotan River & 1,800 & $79^{\circ} 26^{\prime}$ & $36^{\circ} 52^{\prime}$ & 1957-2006 \\
\hline Kaqung & Yarkant River & 1,370 & $76^{\circ} 54^{\prime}$ & $37^{\circ} 59^{\prime}$ & 1957-2006 \\
\hline Sharikilank & Aksu River & 2,000 & $78^{\circ} 36^{\prime}$ & $40^{\circ} 57^{\prime}$ & 1957-2006 \\
\hline Xehera & Aksu River & 1,487 & $79^{\circ} 37^{\prime}$ & $41^{\circ} 34^{\prime}$ & 1957-2006 \\
\hline Dashankou & Kaidu River & 1,340 & $85^{\circ} 44^{\prime}$ & $42^{\circ} 13^{\prime}$ & $1956-2006$ \\
\hline Allar & Tarim River & 1,012 & $81^{\circ} 05^{\prime}$ & $40^{\circ} 50^{\prime}$ & 1960-2006 \\
\hline Kara & Kashigar River & 1,900 & $75^{\circ} 12^{\prime}$ & $39^{\circ} 33^{\prime}$ & $1958-2006$ \\
\hline
\end{tabular}

\subsection{Partial correlations}

Partial correlation analysis is a method to study the linear correlation between two variables whilst they are partially correlated with the linear effect of another variable. Partial correlation coefficient is called the 'first order partial correlation' when the two variables correlate with one further variable. A partial correlation coefficient quantifies the correlation between two variables while they influence one or several other variables. What exactly is the correlation $r_{y 1.2}$ between variables $x_{1}$ and $y$ conditioning on $x_{2}$ ? It is the correlation between the parts of $x_{1}$ and $y$ that are uncorrelated with $x_{2}$. To obtain these parts of $x_{1}$ and $y$, they are both regressed on $x_{2}$. The residuals of the regression are then the parts of $x_{1}$ and $y$ that are uncorrelated with $x_{2}$. The correlation between these residuals of $x_{1}$ and $y$ is the partial correlation between $x_{1}$ and $y$ when conditioning on $x_{2} . r_{y 1.2}$ is a first-order partial correlation coefficient because it is conditioned solely on one variable $\left(x_{2}\right)$ (De La Fuente et al., 2004; Yu et al., 2007).

The linear function of $x_{2}$ was controlled when analysis showed partial correlation with and between $x_{1}$ and $y$ variables. The first order partial correlation coefficient quality of $x_{1}$ and $y$ is defined as:

$$
r_{y 1,2}=\frac{r_{y 1}-r_{y 2} r_{12}}{\sqrt{\left(1-r_{y 2}^{2}\right)\left(1-r_{12}^{2}\right)}} \text {. }
$$

Where $r_{y 1}, r_{y 2}, r_{12}$ stand for the correlation coefficient of $y$ and $x_{1}, y$ and $x_{2}$, and $x_{1}$ and $x_{2}$, respectively. Partial correlation coefficients range from -1 to +1 . When $r_{y 12}$ is greater than 0 , this indicates that there is a positive linear relationship between two variables; when $r_{y 12}$ is smaller than 0 , this indicates that there is a negative 
linear correlation between two variables; when $r_{y 12}=1$, this indicates that there is perfect positive correlation; when $r_{y 12}=-1$, this indicates perfect negative correlation exists between two variables; when $r_{y 12}=0$, there is no linear relationship between the two variables.

Thus we can use partial correlation coefficients to distinguish between the correlations of two variables due to direct causal relationships from the correlations between the same two variables that originate via intermediate variables (sequential pathways) or directly due to other variables (common causes). Although partial correlation analysis still does not infer causal relationships, it excludes many of the possibilities, and thus is a step in the direction of causal inference (Shipley, 2002).

The test statistic for partial correlation analysis is called $t$ statistic, and is defined mathematically as:

$$
t=r \sqrt{\frac{n-q-2}{1-r^{2}}} .
$$

Where, $r$ is the partial correlation coefficient; $n$ is the number of samples; $q$ is the order; $n-\mathrm{q}-2$ is the freedom. The null hypothesis $\left(\mathrm{H}_{0}\right)$, this is, the relationship between runoff and temperature/precipitation is not significant correlation, is accepted if the test statistic $\mathrm{T}$ is not statistically significant.

\subsection{Exponential smoothing}

The Holt double exponential smoothing model can be applied to time series data with a trend. Exponential smoothing is a procedure for continually revising a forecast in the light of more recent experience. In other words, recent observations are given relatively more weight in forecasting than the older observations. The trend is a smoothed estimate of average growth at the end of each period (Taylor et al., 2003; James et al., 2004; Prajakta et al., 2004; Baki et al., 2007; Sarah et al., 2010).

Double exponential smoothing applied to time series data, the first smoothing formula is shown as:

$$
f_{t}^{(1)}=a y_{t}+(1-a) f_{t-1}^{(2)} \text {. }
$$

The second smoothing formula is:

$$
f_{t}^{(2)}=a f_{t}^{(1)}+(1-a) f_{t-1}^{(2)} \text {. }
$$

Where, $f_{t}^{(1)}$ is an exponential smoothing value; $f_{t}^{(2)}$ is double exponential smoothing value; The Holt double smoothing is not applied directly to the second exponential smoothing. The original sequence data and the trend series are smoothed, respectively.

The model's general form is:

$$
f_{t+m}=S_{t}+b_{t} m
$$

Where, $S_{t}$ and $b_{t} m$ are two parameters in the model.

The specific formula for simple exponential smoothing is:

$$
\begin{aligned}
& S_{t}=a y_{t}+(1-a)\left(S_{t-1}+b_{t-1}\right) \\
& b_{t}=\gamma\left(S_{T}-S_{t-1}\right)+(1-\gamma) b_{t-1} .
\end{aligned}
$$

Where, $S_{t}$ is smoothed value; $b_{t}$ is smoothed value for the trend which is the difference between two adjacent smoothed values; $\gamma$ is the initial parameter for the model.

\subsection{Autoregressive Integrated Moving Average Model modeling in time series analysis}

The time series data of the Allar station during the period of 1957-2007 were used as the forecast. The basic idea of the Autoregressive Integrated Moving Average Model (ARIMA) is to use the time series of past values and present values of the linear combination to predict its future values (Yin et al., 2010). This model-building process is designed to take advantage of associations in the sequentially lagged relationships that usually exist in data collected periodically.

The transformed series were different at the mean, and corrected to induce stationarity. Sample autocorrelation and partial autocorrelation functions were used to identify the ARIMA model of the appropriate order. Estimates of the model's parameters were obtained by the maximum likelihood method. Diagnostic checking included residual analysis and the Akaike Information Criterion (Yin et al., 2010) was used to compare goodness-of-fit among ARIMA models. The final model was a result of several iterations of the identification, estimation, and checking process, and met the conventional criteria for the adequacy of the model (Mohammad et al., 2006; Saeed et al., 2009; Yin et al., 2010).

The basic processes of ARIMA modeling are: (1) Smoothing the data series; (2) Calculating the autocorrelation and partial correlation coefficients to assess pretreatment ARMA modeling data requirements; (3) Identifying ARIMA model (according to the truncation of autocorrelation (AC) and partial correlation coefficients (PAC), the type of model could be identified); (4) Estimating the parameter and testing the fit of the ARIMA model; and (5) Predicting future trends 
using the ARIMA model.

\section{Results and discussion}

\subsection{Trend of temperature, precipitation and runoff time series}

In the past 50 years, the temperature of the Tarim River Basin shows a trend of continuous increase, especially in the four headstreams of the Tarim River (Fig. 2). The average annual temperatures of the Aksu River, Hotan River, Yarkant River and Kaidu River had the increasing trends of $0.27^{\circ} \mathrm{C} / 10 \mathrm{a}, 0.31^{\circ} \mathrm{C} / 10 \mathrm{a}$, $0.04^{\circ} \mathrm{C} / 10 \mathrm{a}$, and $0.18^{\circ} \mathrm{C} / 10 \mathrm{a}$, respectively. The average annual temperature of the Hotan River showed a clearly, monotonously increasing trend. In the 1990s, the Kaidu River had a large increase in temperature, while there was a significant drop in average temperature in Yarkand River. The increase in temperature resulted in a significant increase in runoff. In the 1960s, there were serious droughts in the basin (Wang et al., 1996). In the mid 1970s to $1980 \mathrm{~s}$, there was a conversion period, and the situation of drought and flood was more serious. Since the late 1980s, drought appeared to be decreased and floods increased. Since the mid 1990s, the situation of downstream was quite different from the rests of the basin (Su et al., 2007).
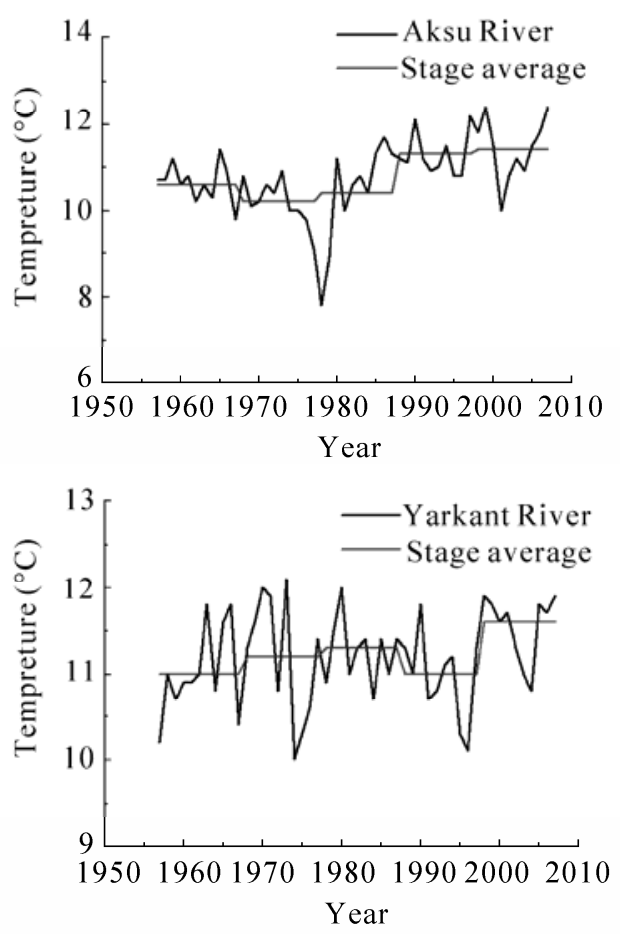

Fig. 2 Average annual temperature in four major headstreams of the Tarim River

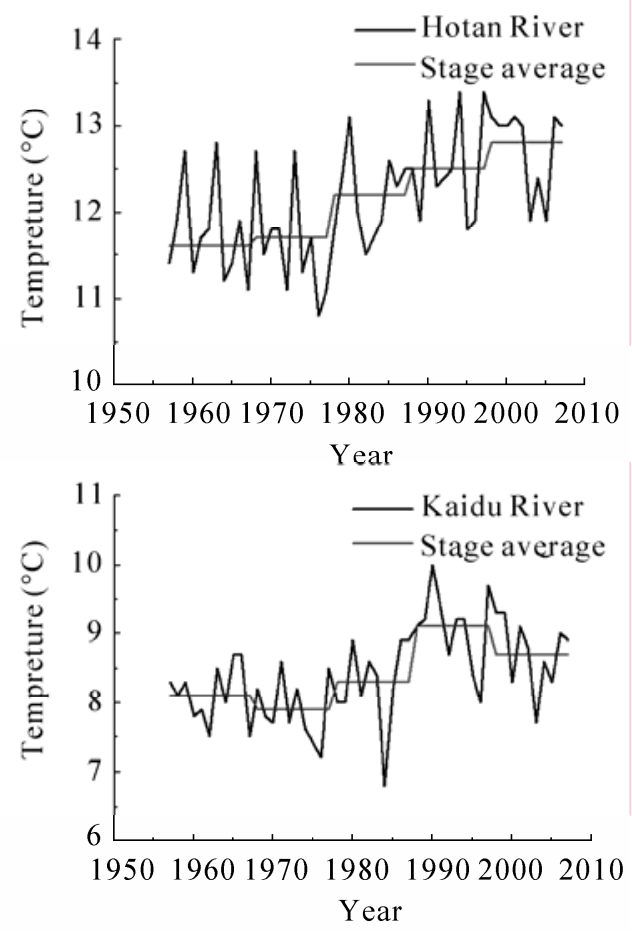

In the past 50 years, the precipitation at every section of the Tarim River Basin has increased (Fig. 3). The annual precipitations of Aksu, Hotan, Yarkant and Kaidu rivers had the increasing trends of $12.5 \mathrm{~mm} / 10 \mathrm{a}$, $4.5 \mathrm{~mm} / 10 \mathrm{a}, 11.2 \mathrm{~mm} / 10 \mathrm{a}$, and $8.0 \mathrm{~mm} / 10 \mathrm{a}$, respectively. According to the data for Hotan and Yarkand rivers, the years of positive above average values are roughly the same as those for negative below average values, while on the Aksu and Kaidu rivers, the years of positive values became more common after 1987. The values of the linear trends of the Aksu, Hotan, Yarkand and Kaidu fivers were 2.19, 0.29, 0.56, and 1.05 , respectively. Increased evaporation rates resulted in reductions in river runoff. However, this was more than balanced by the increased rates of precipitation, and so, overall, river runoff increased.

In the past 50 years, the Aksu, Yarkant and Kaidu rivers have exhibited the increasing trends in annual runoff. The streamflow in the Aksu River showed a significantly, monotonously increasing trend at a slope of 0.74 . However, there has been a subtle reduction in runoff in the Hotan River, at a slope of -0.42 (Fig. 4). Particularly in the 1990 s, wet-years appeared to be more common and the natural runoff from mountains also shown an upward trend. The 1990s was an important abrupt point of climate change when the 

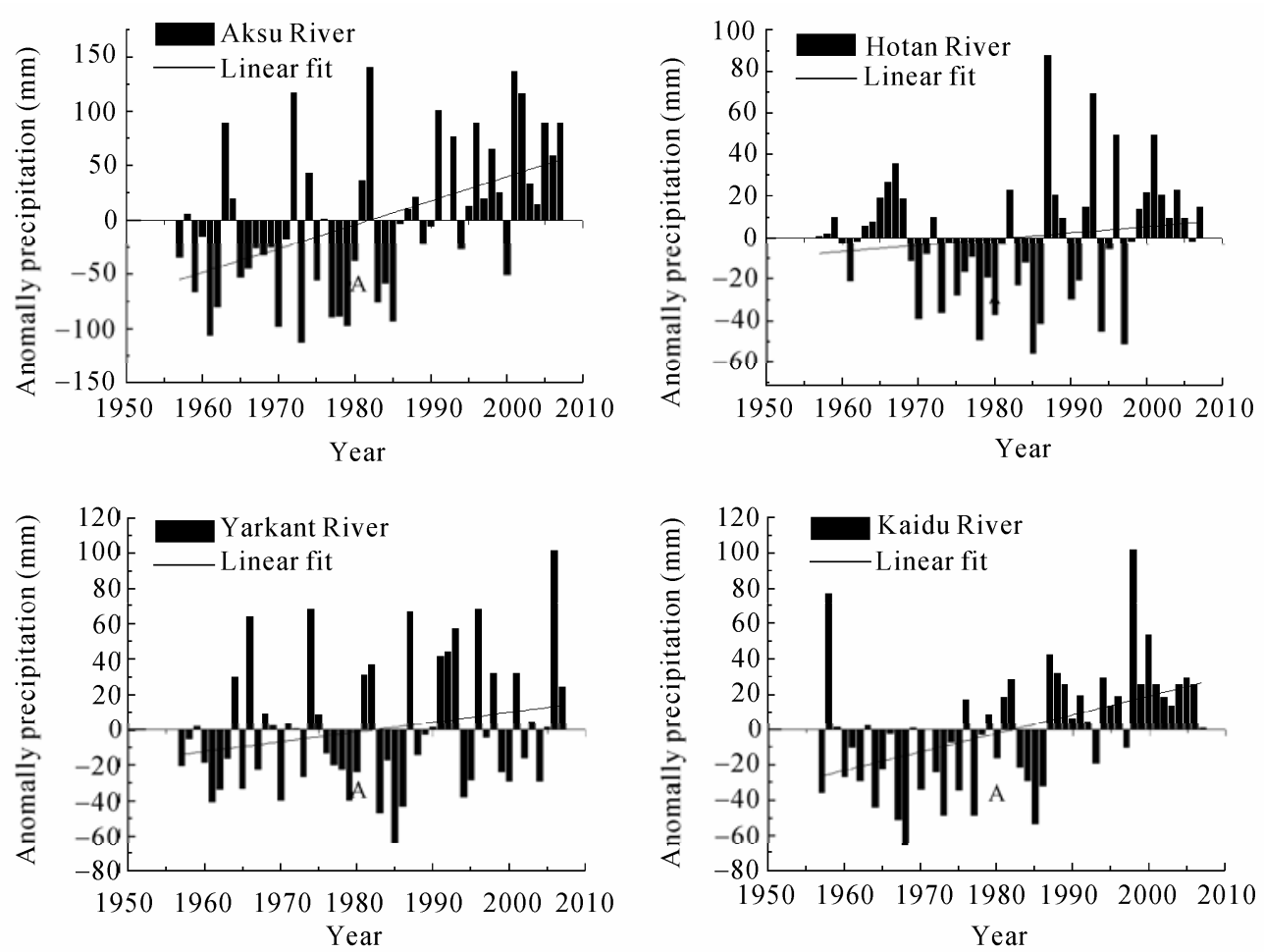

Fig. 3 Annual anomaly precipitation in four major headstreams of the Tarim River
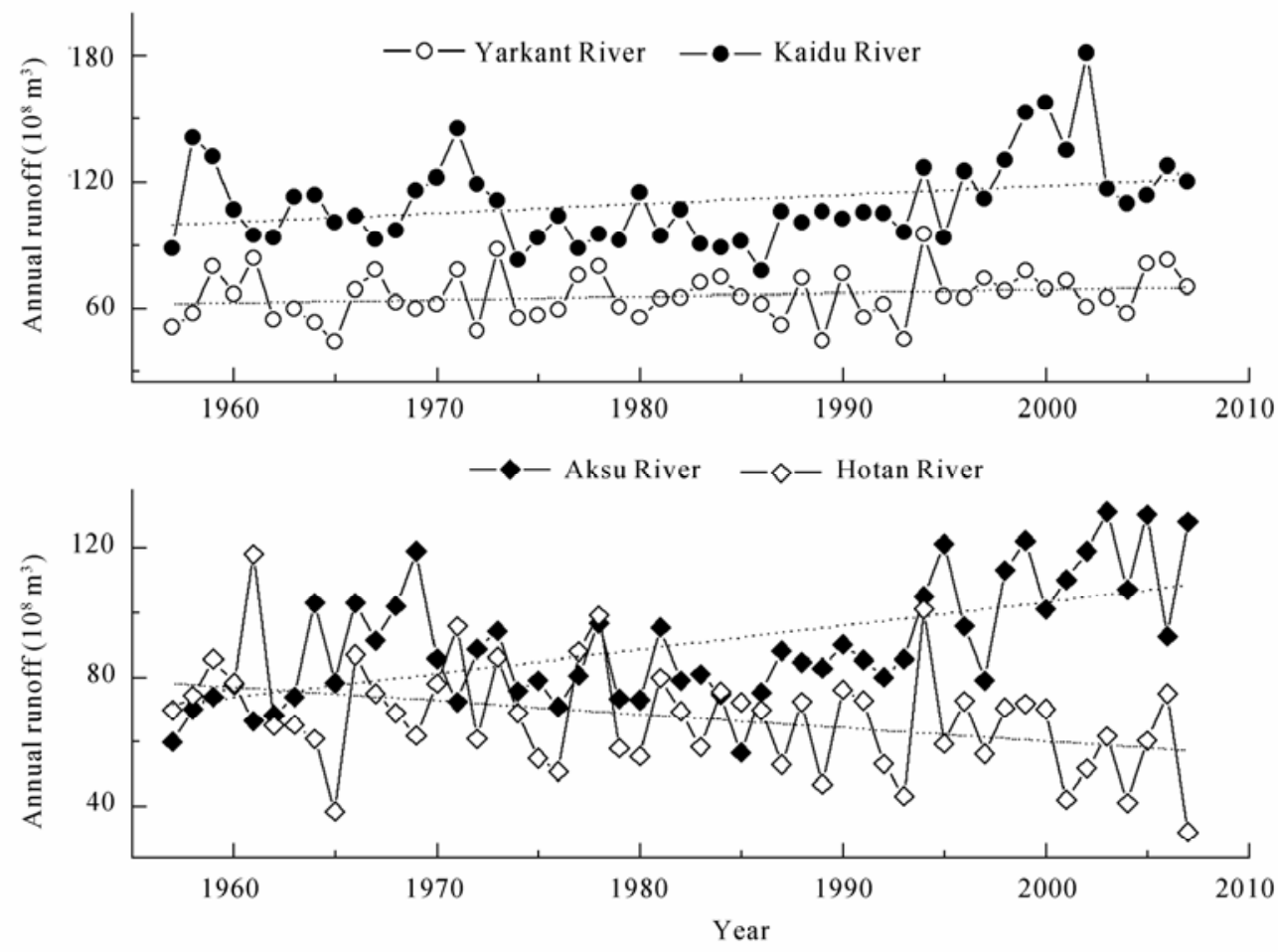

Fig. 4 Annual anomaly runoff in four major headstreams of the Tarim River

temperature showed a significant increase and the river runoff increased. As a headstream of the Tarim River, the decrease of runoff in the Hotan River due to decreased glacier melting is larger than that in the
Kaidu River during the 1970s-1980s due to the decreased precipitation (Xu et al., 2006). On the other hand, the increase in glacier melt water in the 1990's produced an increasing rate of runoff greater than the 
rate of increase from precipitation. In the past 50 years, the Aksu River has shown a trend of increasing runoff, and an increased possibility of flooding in summer. This may be related to the geographic distribution of the headstreams. Those rivers that mainly relied on the supply of glacier melt water have shown an increasing trend in annual runoff when temperature increased. However, water flow in the mainstream has been declining when compared to the rising flow rates in the headstreams. From the 1950s to 2006, water flowing into the Tarim River from the four headstreams reduced by $1,514 \times 10^{8} \mathrm{~m}^{3} / \mathrm{a}$ (Duan et al., 2009).

\subsection{Partial correlation analysis between runoff, temperature and precipitation}

Table 2 shows the partial correlation analysis for taking precipitation/temperature as a control variable. Firstly, the associated analyses were carried out on the four headstreams' average annual runoff, average annual temperature and average annual precipitation, and then we took the average annual temperature or precipitation as a control variable to do partial correlation analysis.

Table 2 The partial correlation analysis between runoff and temperature and precipitation of the four headstreams

\begin{tabular}{ccccc}
\hline Item & Aksu River & Hotan River & Yarkant River & Kaidu River \\
\hline $\mathrm{P}$ & $0.410^{* *}$ & $-0.393^{* *}$ & -0.147 & $0.515^{* * *}$ \\
$\mathrm{~T}$ & 0.230 & -0.079 & $0.276^{*}$ & 0.255 \\
$\mathrm{P}($ Control T) & $0.369^{* *}$ & $-0.398^{* *}$ & None & $0.468^{* * *}$ \\
$\mathrm{~T}($ Control P) & None & None & 0.266 & None \\
\hline
\end{tabular}

Note: *,** and $* * *$ indicate the significance at the levels of $P<0.05, P<$ 0.01 , and $P<0.001$, respectively.

The correlation between average annual runoff and average annual precipitation is significant for the Aksu River, and highly significant for the Kaidu River, but for the Hotan River, it is negatively significant. Because the partial correlation coefficients of the three headstreams (Aksu River, Hotan River and Kaidu River) have no significant differences, the hypothesis that the correlation between average annual runoff and average annual precipitation is significant has to be rejected. The correlation between average annual runoff and average annual temperature for the Yarkand River is significant, however, the result of partial correlation coefficient of the two populations had no significant differences. And the null hypothesis is not rejected, so the correlation between average annual runoff and average annual temperature is not significant.

In conclusion, the changes in temperature and precipitation had great impact on runoff in the four headstreams, in which the precipitation had a large positive impact on the Aksu River and the Kaidu River, a negative impact on the Hotan River, but temperature had a positive influence on the Yarkand River, whereas the changes in temperature had a very weak linear effect on the Hotan River runoff. The changing of the surface runoff originated from climate change. The special hydrological characteristics of the arid zone determine the significant associations between streamflow and the two climatic factors, precipitation and temperature.

\subsection{Holt Double Exponential Smoothing Model fitting between runoff and temperature or precipitation}

The Holt Double Exponential Smoothing Model was used to fit the two variables (runoff and temperature/precipitation), which is equivalent to linear regression analysis. Table 3 shows the fit for average annual runoff and average annual temperature/precipitation of three of the headstreams (Aksu River, Hotan River and Yarkand River) of the Tarim River, following Holt Double Exponential Smoothing. The multiple correlation coefficients for the Aksu River, Hotan River and Yarkand River indicate that there was a strong connection between the independent variable and the dependent variable (Fig. 4). The Kaidu River had no condition to do exponential smoothing, and runoff had no strong connection with temperature/precipitation when trend fitting. It implies that the fit between the independent variable and the dependent variable was relatively close. A significant negative correlation between runoff and temperature was shown for only the Hotan River, while significant positive correlations were shown between precipitation and runoff for the Aksu and Yarkand rivers. Temperature affects glacier melt and accumulation of melt water, and elevated temperatures result in strong repercussions for extensive glacier melting (Jiang et al., 2007). As precipitation increased, runoff increased in the rivers which had a small proportion of glacier melting, and runoff reduced in the rivers which had a major proportion of glacier melting. 


\subsection{Trend analysis of the runoff in the main Tarim River stream}

The parameters' estimates and five forecast values for the optimum ARIMA $(0,1,1)$ are shown in Table 4 . There were 48 observations used to make the forecast, and only one observation was eliminated by difference. The autocorrelation and partial autocorrelation functions of the residuals showed good-fit (Fig. 5).
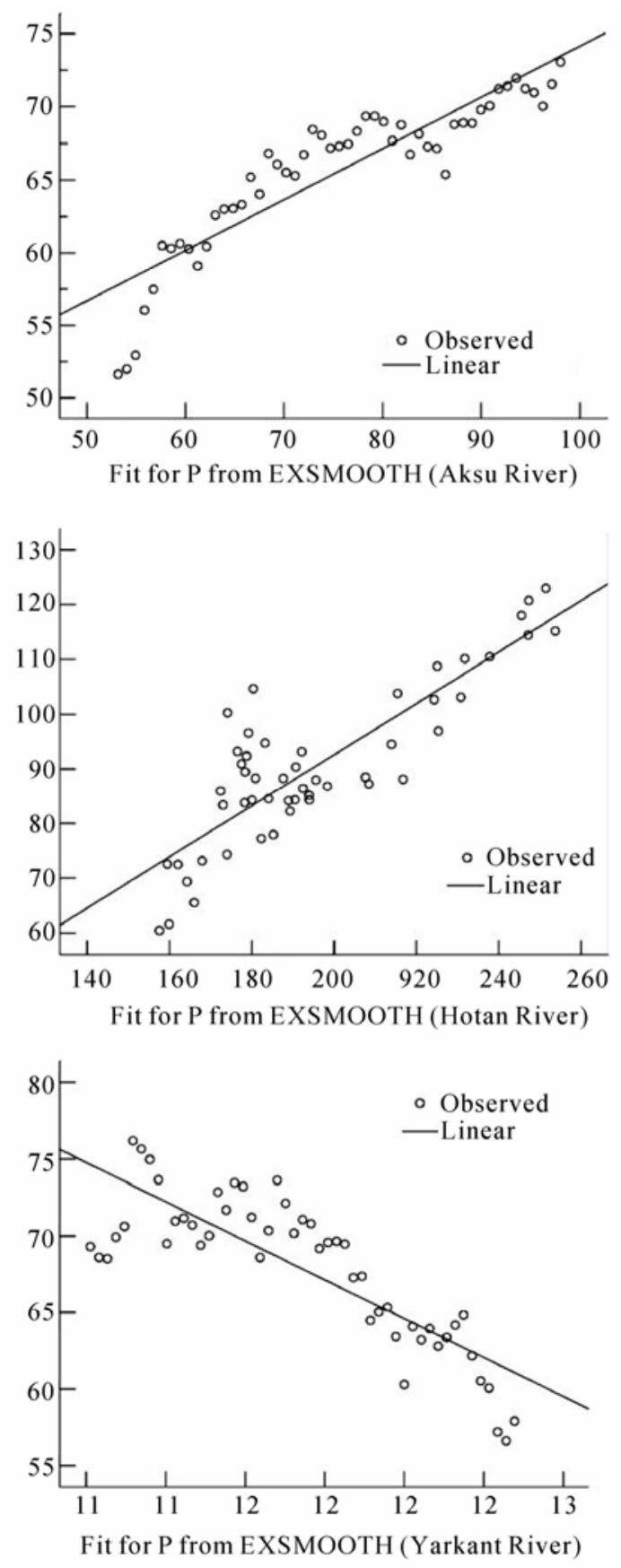

Fig.5 Trends fitting between runoff and temperature or precipitation of three head streams
The goodness of fit test of the optimum ARIMA ( 0 , $1,1)$ model showed non-significant autocorrelations in the residuals of the model. The estimate value is high enough to be strongly significant, indicating that ARIMA $(0,1,1)$ fits the data well and is suitable for accurate forecasting (Table 4). Drawing the curve of the data revealed overall changes to runoff in the main river. Streamflow at Allar station, the first hydrological gauging station in the mainstream, displayed a decreasing trend, and the trend is statistically significant $(P<0.05)$ (Fig. 6), while annual streamflow in the headwater catchments exhibited an increasing trend (Chen et al., 2008). The results of the temperature analysis showed that increases in air temperature had resulted in the increasing of streamflow in the Tarim River during the last 50 years. It may result in the decrease of runoff in the plain area due to an increase in evaporation. However, the negative trends in streamflow in the Tarim River have mainly resulted from anthropogenic activities. The potential impact of climate on the study area is relatively slow compared to the impacts caused by human activity. In order to deal with the issue of decreasing downstream water supplies caused by human activities and their impact on

Table 3 Holt Double Exponential Smoothing fitting between runoff and temperature or precipitation of three headstreams

\begin{tabular}{cccc}
\hline Aksu River & Model & \multicolumn{2}{c}{ Parameter estimation } \\
\hline Equation & R Square & Constant & $\mathrm{b} 1$ \\
Linear & $0.729^{* * *}$ & -1.028 & 0.468 \\
\hline Hotan River & Model & Parameter estimation \\
\hline Equation & R Square & Constant & $\mathrm{b} 1$ \\
Linear & $0.688^{* * *}$ & 171.354 & -8.472 \\
\hline Yarkant River & Model & Parameter estimates \\
\hline Equation & R Square & Constant & $\mathrm{b} 1$ \\
Linear & $0.804^{* * *}$ & 39.233 & 0.349 \\
\hline
\end{tabular}

Note: $* * *$ indicates the significance at the level of $P<0.001$.

Table 4 Autoregressive integrated moving average model $(0,1$, 1) of the Allar station

\begin{tabular}{ccccc}
\hline \multicolumn{2}{c}{ Parameters } & Estimating & Standard error & t-ratio \\
\hline \multicolumn{2}{c}{ Autoregressive parameter } & 1.00 & 0.07 & 13.10 \\
\cline { 3 - 5 } Observation & Forecast & Std. error & \multicolumn{2}{c}{ Confidence limits of 95\% } \\
\hline 1 & 42.0405 & 10.2101 & 22.0289 & 62.0520 \\
2 & 41.9117 & 10.2101 & 21.9002 & 61.9232 \\
3 & 41.7829 & 10.2101 & 21.7714 & 61.7944 \\
4 & 41.6542 & 10.2101 & 21.6426 & 61.6657 \\
5 & 41.5254 & 10.2101 & 21.5139 & 61.5369 \\
\hline
\end{tabular}




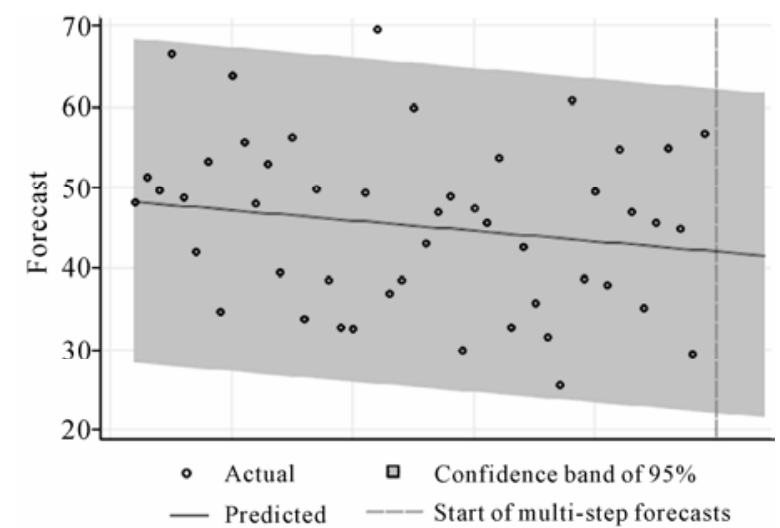

Fig. 6 Forecasts values $\left(10^{8} \mathrm{~m}^{3}\right)$ of the runoff at Allar station for the final ARIMA $(0,1,1)$ in Tarim River during the period of 1957-2007

deterioration of the ecological environment, we should develop ecological water assurance and watersheds vegetation protection. It is necessary to establish effective water resource management and control mechanisms throughout the basin (Xie et al., 2007). It should be implemented through rational allocation of water resources in the upstream rivers and upper and middle reaches of the Tarim River, along with a corresponding increase in the promotion of water recycling and reutilization in agriculture, industry, and daily life.

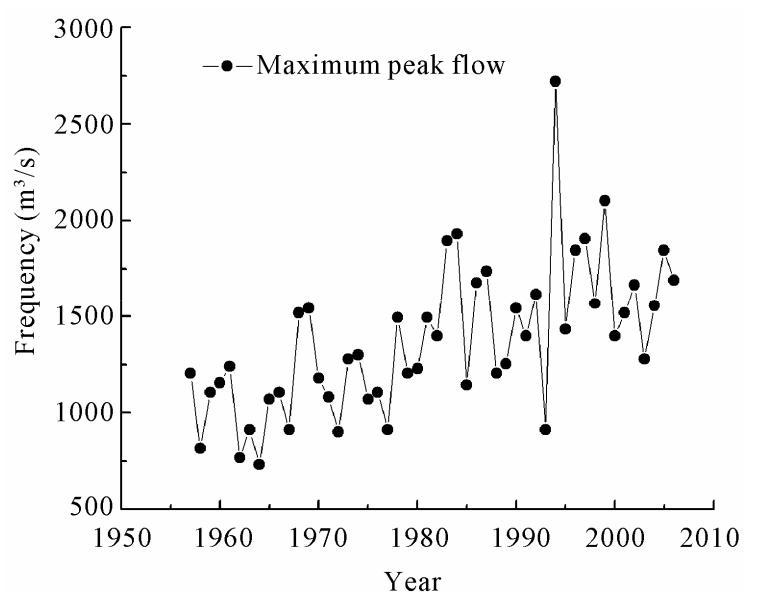

Fig. 7 The peak discharge variation at Xehera station during the period of 1957-2006

If the temperature continues to rise, the snow-line will retreat upslope, and glaciers will shrink, and the thaw area will increase, and the snow and ice accumulation area will decrease. Due to the significant increase of surface temperature, runoff from glacier melting is likely to increase significantly in future, increasing the risk of flooding in the headstream and further downstream. Some relative researches show that the glaciers whose areas are less than $1 \mathrm{~km}^{2}$ will completely melt in 50 years (Ding, 2010). In the upper reaches of the Tarim River, where flow mainly relies on the supply of glacier melt water, a short-term increase in glacier melt would regulate the river runoff. When precipitation is inadequate to replenish and replace the glaciers' melt water, the degradation of glaciers will inevitably affect the environment and human habitat in the future (Xu et al., 2006). On the Aksu River, the largest one of the headstreams of the Tarim River, glacier melt water flows are changing as glaciers retreat, and peak runoff volume is increasing. Figure 6 shows the variation in peak discharge each year at Xehera station in 1957-2006. Xehera station is located on the Aksu River, with a natural hydraulic linkage to the mainstream of the Tarim River, and located in the mountains where anthropogenic disturbance is negligible. The data in Fig. 6 shows that the maximum peak flow each year has followed an increasing trend during the past 50 years, reaching to $2,720 \mathrm{~m}^{3} / \mathrm{s}$ in 1994. The Tarim River Basin has warmed since the late 1970's (Fig. 2), and this in turn has affected the distribution of the basin's glaciers, frozen soil and snow, with significant impacts on the region's agricultural production and people's lives. Peak flows for melt water carry a high frequency than peak flows for rainfall in middle zone of mountains. Peak flows for melt water is closely related to rising temperature and melting glaciers in high mountains, and it always happens in summer. In the past 20 years, the increased runoff in mountains has some connection with the increased temperature under the background of global climate change (Chen and $\mathrm{Xu}, 2005)$. In addition, sudden floods often occur in the Yarkant River and the Aksu River. It may result from glacial barrier lakes releasing flood suddenly. The rate of sudden floods for melt water has an increasing tendency in the Tarim River Basin (Chen et al., 2010). In order to deal with the problem that temperatures continue rising, leading to increased glacier melting, a flood prevention and water use plan should be drawn up to reduce flooding risk and take advantage of the additional water in the peak flows. Flood control installations should be built in flood-prone areas as early as possible, while estimates of the amount of additional water 
resources from accelerated glacier melting should be calculated as soon as possible (Chen et al., 2004).

\section{Conclusions}

Our results reveal that the headwaters of the Tarim River Basin have become warmer and wetter in the last 50 years. The annual runoff exhibited a significant correlation with the temperature and precipitation in the four major headstreams. Precipitation had a greater positive impact on flow rates in the Aksu, Hotan and Kaidu rivers, but temperature had the larger positive impact on the flow in the Yarkand River.

The $\mathrm{R}$ value for the multiple correlation model of the three origins indicates a close fit between the independent variable and the dependent variable. A sig-

\section{References}

Arkin T, Askar M, Tursun R, et al. 2007. Recent changes in the river hydrological characteristics of the Tarim River Basin. Journal of Glaciology and Geocryology, 29(4): 543-552.

Baki B, Maxwell L K, Ralph D S, et al. 2006. Exponential smoothing model selection for forecasting. International Journal of Forecasting, 22(2): 239-247.

Chen S Y, Shi Y Y, Guo Y Z, et al. 2010. Temporal and spatial variation of annual mean air temperature in arid and semiarid region in northwest China over a recent 46 year period. Journal of Arid Land, 2(2): 87-97.

Chen Y N, Xu Z X. 2005. Plausible impact of globe climate change on water resources in the Tarim River Basin, China. Science in China: Series D, 48(1): 65-73.

Chen Y N, Xu C C, Hao X M, et al. 2008. Fifty-year climate change and its effect on annual runoff in the Tarim River Basin, China. Journal of Glaciology and Geocryology, 30(6): 921-929.

Chen Y N, Xu C C, Yang Y H, et al. 2009. Hydrology and water resources variation and its responses to regional climate change in Xinjiang. Acta Geographica Sinica, 64(11): 1331-1341.

Chen Y N, Xu C C, Chen Y P, et al. 2010. Response of glacial-lake outburst floods to climate change in the Yarkant River basin on northern slope of Karakoram Mountains, China. Quaternary International, 226(1): 75-81.

De La Fuente A, Bing N, Hoeschele I, et al. 2004. Discovery of meaningful associations in genomic data using partial correlation coefficients. Bioinformatics, 20(18): 3565-3574.

Deng M J. 2006. Changes of climate and runoff in Tarim River Basin and ecosystem restoration in the lower reaches of Tarim River. Journal of Glaciology and Geocryology, 28(5): 193-196.

Ding H, Chen Y N, Li W H, et al. 2007. Distributed hydrological model based on DEM in Qingshui River Basin. Arid Land Geography, 30(3): 364-369.

Ding Y J, Han T D. 2010. The assessment of climate change impact on water resources in western China over the past 100 years. Integrative Research on Environmental Evolution in Western China, 30(3): 302-326.

Dong S, Xu J H, Chen Y N, et al. 2009. Fractal characteristics of annual mean temperature of the Tarim Basin. Arid Land Geography, 32(1): nificant negative correlation was shown only between runoff and temperature for the Hotan River, and a significant positive correlation was shown between precipitation and runoff for the Aksu and the Yarkand rivers. The model is statistically significant.

Annual streamflow for the Allar station represents overall changes and annual fluctuations in the headstream flows into the Tarim River. Analysis of annual streamflow data for the period of 1957-2007 showed that the runoff (streamflow) flowing through Allar station displayed a significant decreasing trend.

\section{Acknowledgements}

The research is supported by the National Basic Research Program of China (2010CB951003).

\section{7-22.}

Duan J J, Wang Y G, Wang X F, et al. 2009. Impact of climate change and human activities on the water resources and ecological environments in the Tarim River Basin in 1957-2006. Journal of Glaciology and Geocryology, 31(5): 781-791.

Duan K Q, Yao T D, Wang N L, et al. 2007. Records of precipitation in the Muztag Ata Ice core and its climate significance to glacier water resources. Journal of Glaciology and Geocryology, 29(5): 680-684.

Fu L X, Chen Y N, Li W H, et al. 2009. Analyses of the durative and tendency of annual runoff in the headwaters of the Tarim River in the recent 50 years. Journal of Glaciology and Geocryology, 31(3): 457-463.

Fu L X, Chen Y N, Li W H, et al. 2010. Relation between climate change and runoff volume in the headwaters of the Tarim River during the last 50 years. Journal of Desert Research, 30(1): 204-209.

Gao Q Z, Wang R, Ernst G, et al. 2008. Impact of climate change on surface runoff of Tarim River originating from the south slopes of the Tianshan Mountains. Journal of Glaciology and Geocryology, 30(1): $1-11$.

Hao X M. 2008. Tarim River runoff changes in human activity and climate change factor screening. Progress in Natural Science, 18(12): 1409-1416.

James W T. 2004. Smooth transition exponential smoothing. Journal of Forecasting, 23(6): 385-404.

Jiang Y, Xia J. 2007. The hydrological characteristics of runoff and its response to climatic change in Tarim. Resources Science, 29(3): $45-52$.

Li H J, Jiang Z H, Wei W S. 2007. Drought and flood change of Tarim River Basin in recent 40 years. Scientia Geographica Sinica, 27(6): 801-807.

Liu S Y, Ding Y J, Zhang Y, et al. 2006. Impact of the glacial change on water resources in the Tarim River Basin. Acta Geographica Sinica, 61(5): 118-123.

Meng L H, Chen Y N, Li W H. 2008. Study of water resources carrying capacity in Tarim River Basin of Xinjiang. Journal of Desert Research, 28(1): 185-190.

Mohammad A. 2006. The predictability of the Amman stock exchange using the univariate autoregressive integrated moving average 
(ARIMA) model. Journal of Economic Administrative Sciences, 22(2): 1-18.

Prajakta S K. 2004. Time series forecasting using Holt-Winters Exponential Smoothing. Kanwal Rekhi School of Information Technology, $1-13$.

Saeed A, Shafquat R. 2009. An autoregressive integrated moving average model for short-term prediction of hepatitis $\mathrm{C}$ virus seropositivity among male volunteer blood donors in Karachi, Pakistan. World Journal Gastroenterol, 15(13): 1607-1612.

Sarah G, Roland F, Christophe C. 2010. Robust Forecasting with Exponential and Holt-Winters Smoothing. Journal of Forecasting, 29(3): 285-300.

Shen Y P, Wang G Y, Su H C, et al. 2007. Hydrological processes responding to climate warming in the upper reaches of Kelan River Basin with snow-dominated of the Altay Mountains region, Xinjiang, China. Journal of Glaciology and Geocryology, 29(6): 845-854.

Shen Y P, Wang G Y, Ding Y J, et al. 2009a. Changes in Merzbacher Lake of Inylchek glacier and glacial flash floods in Aksu River Basin, Tianshan during the period of 1903-2009. Journal of Glaciology and Geocryology, 31(6): 993-1002.

Shen Y P, Wang G Y, Ding Y J, et al. 2009b. Changes in glacier mass balance in watershed of Sary Jaz-Kumarik Rivers of Tianshan Mountains in 1957-2006 and their impact on water resources and trend to end of the $21^{\text {th }}$ Century. Journal of Glaciology and Geocryology, 31(5): 792-800.

Shi Q D, Chen L J, Pan X L, et al. 2003. Characteristics of vegetation evolution in arid land of western China using remote sensing images from 1982 to 1990. Resources Science, 25(5): 84-88.

Shi Y F. 2001. Estimation of the water resources affected by climatic warming and glacier shrinkage before 2050 in west China. Journal of Glaciolgy and Geocryology, 23(4): 333-341.

Su H C, Shen Y P, Han P, et al. 2007. Precipitation and its impact on water resources and ecological environment in Xinjiang region. Journal of Glaciology and Geocryology, 29(3): 343-350.

Sun D Y, Yilihamu, Feng S, et al. 2009. Progress in the study on conjunctive regulation of surface water and groundwater in arid inland river basins. Progress in Geography, 28(2): 167-173.

Tao H, Wang G Y, Shao C, et al. 2007. Climate change and its effects on runoff at the headwater of Kaidu River. Journal of Glaciology and Geocryology, 29(3): 413-417.

Taylor J W. 2003. Short-term electricity demand forecasting using Double Seasonal Exponential Smoothing. Journal of the Operational Research Society, 54: 799-805.

Tursun K, Manisahan T, Han G H, et al. 2009. Analysis on impact factors of land desertification in lower reaches of Tarim River in past 50 years. Journal of Desert Research, 29(6): 1029-1034.

Wan J T, Zhang J G, Miao Y. 2007. Analysis of ice jam floods in river basins on the north slope of middle section of Tianshan Mountains, Xinjiang. Journal of Glaciology and Geocryology, 29(5): 819-823.

Wang G Y, Shen Y P, Su H C, et al. 2008. Runoff changes in Aksu River Basin during 1956-2006 and their impacts on water availability for Tarim River. Journal of Glaciology and Geocryology, 30(4): 562-568.

Wang J. 2009. Analysis of the "four source streams" for the operation of water in Tarim River in 2007. Journal of Glaciology and Geocryology, 31(4): 732-740.

Wang J, Gong W H, Shen Y P, et al. 2009. Effects of riverbed deposition and water consumption on ecological environment in middle and lower sections of upper reaches of mainstream of Tarim River. Journal of Glaciology and Geocryology, 31(6): 1086-1093.

Wang S D, Wang Y G, Wang J, et al. 2003. Change of climate and hy- drology in the Tarim River Basin during past 40 years and their impact. Journal of Glaciology and Geocryology, 25(3): 315-320.

Wu S F, Han P, Li Y, et al. 2003. Predicted variation tendency of the water resources in the headwaters of the Tarim River. Journal of Glaciology and Geocryology, 25(6): 708-711.

$\mathrm{Xu}$ C C. 2006. The process of responding to climate change and hydrological change in Tarim basin during the past 50 years. Chinese Science Bulletin, 51(1): 694-702.

Xu C C, Chen Y N, Li W H, et al. 2007. Climate change and its impact on snow cover area in the Tarim River Basin over the last 45 years. Journal of Glaciology and Geocryology, 29(2): 183-190.

Xu H L, Ye M, Song Y D, et al. 2007. Relationship between climate changes and annual runoff of headstreams of Tarim River. Scientia Geographica Sinica, 27(2): 219-224.

Xu J H, Chen Y N, Li W H. 2008. Checking the nonlinear characteristics of annual runoff processes of inland rivers in arid area of northwest China: A demonstration from the three headwaters of the Tarim River Arid Land Geography, 31(3): 324-332.

Yan W H, Ren Z Y, Zhang C. 2009. Land use change and mapping in the lower reaches of the Tarim River based on Landsat TM images. Resources Science, 31(1): 142-151.

Yan Y H, ShenY P, Li Y A, et al. 2007. Hydrological feature and flood analysis in Keping River on south slope of Tianshan Mountains, Xinjiang. Journal of Glaciology and Geocryology, 29(5): 824-829.

Yang Q, Lei J Q, Wei W S, 2004. Effects of artificial oases on climate change trend. Acta Ecologica Sinica, 24(12): 658-669.

Ye M, Xu H L, Song Y D. 2006. Analysis of water resources utilization and trend in Tarim Basin. Chinese Science Bulletin, 51(1): 38-39.

Ye Z X, Chen Y N, Li W H. 2009a. Ecological water demand of natural vegetation in the lower Tarim River. Journal of Geographical Sciences, 20(2): 261-272.

Ye Z X, Chen Y N, Li W H, et al. 2009b. Effect of the ecological water conveyance project on environment in the Lower Tarim River, Xinjiang, China. Environmental Monitoring and Assessment, 149(1):9-17.

Yin Z D, Luo H M, Li Y X. 2010. The application of autoregressive integrated moving average model on the prediction of Japanese encephalitis cases. Chinese Journal of Vaccines and Immunization, 16(5): 457-461.

Yu N L, Yi D Y, T u X Q. 2007. Analysis of auto-correlations and partial-correlation functions in time series. Mathematical Theory and Applications, 27(1): 54-57.

Zhang J, Liu G X, Shen Y P, et al. 2008. Changes in runoff and climate and the human activity impacts in the Aksu River outside the mountains since the second half of $20^{\text {th }}$ Century. Journal of Glaciology and Geocryology, 30(2): 218-223.

Zhang J B, Wu G H, Wang Q M, et al. 2010. Restoring environmental flows and improving riparian ecosystem of Tarim River. Journal of Arid Land, 2(1): 43-50.

Zhang J G, Wang J W, Ma H M. 2008. Streamflow variations of four source streams to mainstream of Tarim River, Xinjiang and water transportation in 2006. Journal of Glaciology and Geocryology, 30(4): 569-577.

Zhang Y C, Li B L, Cheng W M, et al. 2004. Hydrological response of runoff to climate variation in Kaidu Catchment. Resources Science, 26(6): 69-76.

Zhou H R, Xiao D N. 2010. Ecological function regionalization of fluvial corridor landscapes and measures for ecological regeneration in the middle and lower reaches of the Tarim River, Xinjiang of China. Journal of Arid Land, 2(2): 123-132. 